\section{若手 の声}

北海道支部“若手ネットワーク”より

若手ネットワークとは

日本生物物理学会北海道支部・若手ネットワーク は, 学生やPD が主体となってイベントを企画し, 若 手研究者の交流を推進する団体です. 2006 年から活 動を開始し，2007 年からは生物物理若手の会・北海 道支部としても活動しています。“生物物理”という 名を冠してはいますが，生物物理に限らず幅広い研究 領域からメンバーを募集し，分野横断的な交流の場に なることを目標として活動しています. 2008 年 5 月 現在のメンバー数は 50 人弱です（表 1). そのうち, 主要なメンバーは北海道大学の大学院生で, 修士課 程・博士過程を合わせると約半数の 25 人に達します. また, 13 の研究室から参加者がおり，異分野間の交 流がさかんです.さらに, 参加者の年齢層が幅広く, 上は教授から下は学部 2 年生まで, 非常にバラエティ に富んでいます．教員では特に助教の方が多数ご参加 くださっており，中には「若手と何か大きなことをし

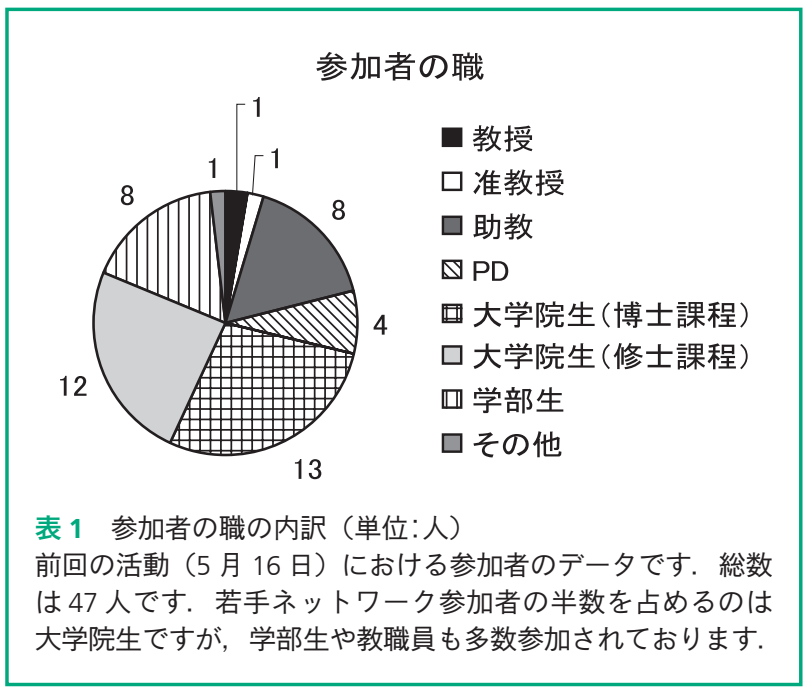

たい！」という情熱的な方もいらっしゃり，心強い限 りです。このように，横のつながりだけでなく縦のつ ながりも強いのが, 若手ネットワークの特徴です.

実質的な運営は，代表の伊東大輔（北海道大学大学 院工学研究科) をはじめとする 4 名の役員が行って います．そのうち，私，田村を含む 3 名は博士課程 の大学院生で, 1 名はPD です。発足してからまだ 2 年程度しか経っておらず，ここ最近はメンバー数の急 激な増加があり, 会の運営は手探りでなかなか大変で すが，この若手ネットワークが若手研究者のコミュニ ティとして北海道を代表する団体に成長することを目 指し，熱意をもって意欲的に取り組んでいます．

\section{若手ネットワークの過去}

若手ネットワークは日本生物物理学会北海道支部の ご後援の下で 2006 年に発足しました. 北海道という 土地柄が影響して，北海道の若手生物物理学会会員は 本州の若手と踈遠で，活躍の機会が少なかったのです が，その状況を憂えた先生方が「若手を元気にさせよ う!」と一念発起してくださったことが, 若手ネット ワーク発足のきっかけでした. 初期のメンバーは, 半 ば強制的に集められたまったく見ず知らずの学生・ PD たちでしたが，ほどなく打ち解けあい，若手ネッ トワークの発展に向けて前進を始めました. 2006 年 7 月 31 日に行われた“研究室紹介セミナー”を皮切 りに活動を開始して以来，定期的にセミナーを開催し てきました. 研究室紹介セミナーだけでなく，ライフ サイエンス分野の企業から講師を招聘してのセミナー を行うなど，新しい試みにも挑戦してきました. ま た， 2007 年に生物物理若手の会の一員となってから は, 若手の会最大のイベントである “夏の学校”に若 手ネットワークのメンバー数名が参加し, 本州の若手 の方々と交流してきました。

\section{若手ネットワークの現在}

今年度第 1 回目の活動として, 若手ネットワーク は“2008 年度の活動内容”を議題とした会議を 5 月 16 日に開催しました. 参加者はこれまで以上にバラ エティに富み，学生・PD はもちろんのこと，北海道 大学の教員や知財本部のスタッフの方もお見えになり ました. 会議では活発に議論が交わされました （図 1).いただいたご意見の一部を紹介しますと「若 手が口頭発表の練習をする場になるような研究発表会 をやってほしい.」「セミナー形式だと一方向的な情報 提供になってしまうので，双方向的なコミュニケー ションができるような企画を設けてほしい.」「北海道 


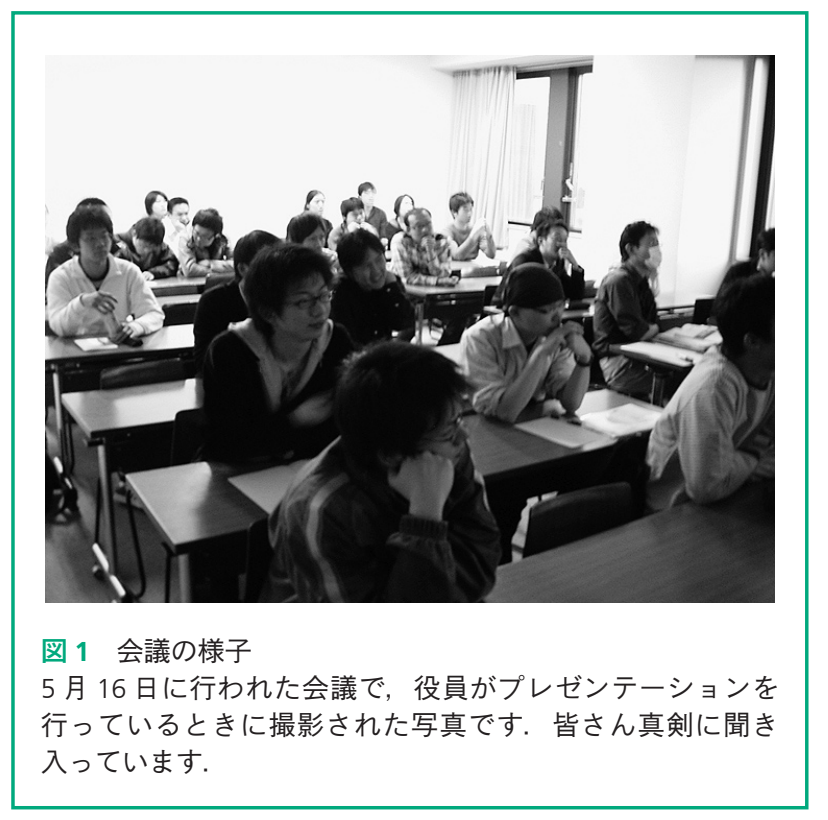

の夏にジンパ(ジンギスカンパーティ;野外でジンギ スカンを食べるバーベキュー形式のパーティのこと） は欠かせない.」などがあげられます. もちろん，会 議の後は盛大に愁親会を行い, 研究内容や進路などに ついておのおのが大いに語り合っていました（図 2).

今年はセミナ一型のイベントだけでなく, 会議で出 されたアイデアをもとに，ワークショップ型のイベン トやフィールド型のイベントも開催していく予定で す. ホームページ (http://altair.sci.hokudai.ac.jp/biophyy/）にて連絡を行っていますので，ぜひ一度ご覧 ください.ほほぼ毎月何らかの活動を行う予定ですの で，若手ネットワークの活動にご興味をおもちで，北 海道にいらっしゃる予定の方がおられましたら，ぜひ ご連絡ください.

\section{若手ネットワークの未来}

2009 年, 若手ネットワークは“生物物理若手の会 第 49 回夏の学校 in 北海道”を主催する予定です．夏 の学校を北海道で開催することは, 若手ネットワーク 設立当初からの目標でした. 北海道は, 大自然と食べ 物（図 3）に恵まれており，そして何といっても“冷 涼”です. したがって, 北海道は夏の学校に非常に適 した環境であると考えています．その念願が叶い，伝 統ある夏の学校を私たちが主催できることは大変光栄 でありがたいことです，しかしながら，歴史の浅い私 たちが，果たして夏の学校をうまく運営できるのかど うか，何しろはじめての取り組みですので，正直なと ころ不安です. そこで, 今後の私たちの活動には, 皆

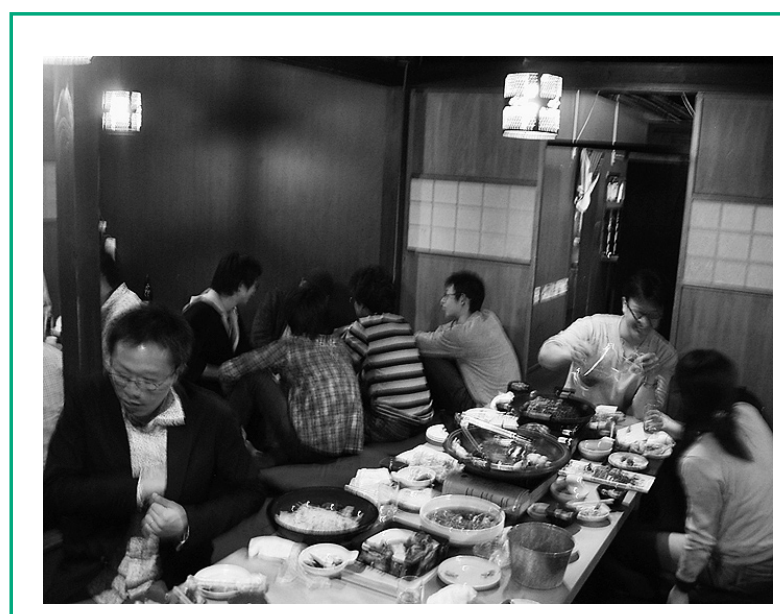

図 2 懇親会の様子

北海道大学近辺の居酒屋にて愁親会を行いました. この後, 2 次会も行い, 宴会は午前 2 時まで続きました.

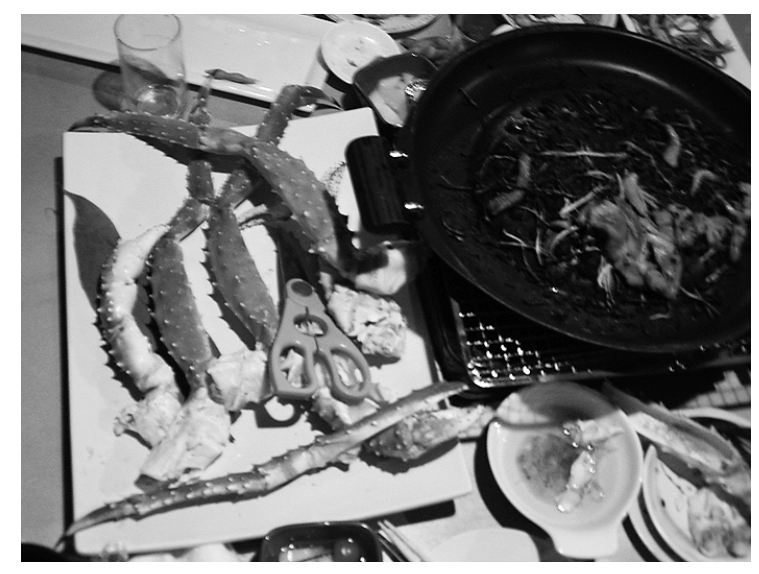

図 3 北海道を代表する食べ物（懇親会のメニューから） 左に見えるのはカニです.このような海の幸を楽しめるのも 北海道の魅力です，その食べにくさから，留親会では放置さ れてしまっていました．．また，右に見える鉄板の上にはジ ンギスカンがありました．こちらは，撮影の前にほぼ食べ尽 くされてしまいました.

様のご協力とご理解が必要です. 夏の学校は, 先述の とおり，生物物理の若手にとって最大のイベントで す. 若手研究者の活躍, 生物物理若手の会の発展, そ して若手ネットワークの成長のためにも，私たちの活 動を暖かく見守っていただき，応援していただければ 幸いです。

最後になりましたが, メンバー一同頑張って参りま すので, 今後とも若手ネットワークをよろしくお願い 致します.

北海道大学大学院理学院生命理学専攻細胞ダイナミクス科学研究室 博士 1 年 田村和志 tam@mail.sci.hokudai.ac.jp 